\title{
Assessing sulfur sources and pyrite precipitation during eclogite-facies intra-slab fluid-flow (Monviso Lower Shear Zone, W. Alps)
}

\author{
ISABELLE GENOT ${ }^{1}$, SAMUEL ANGIBOUST ${ }^{2}$ AND \\ PIERRE CARTIGNY ${ }^{3}$ \\ ${ }^{1}$ Institut de Physique du Globe de Paris \\ ${ }^{2}$ Institut de Physique du Globe de Paris, Sorbonne Paris Cité \\ ${ }^{3}$ IPGP \\ Presenting Author: genot@ipgp.fr
}

The sulfur content and isotopic budget of the sub-arc mantle is still weakly constrained despite its important role in mantle wedge oxidation, ore deposit formation and $\mathrm{SO}_{2}$ emissions by arc volcanoes. In order to better understand its fate and behavior in subduction zones, we analyzed the ${ }^{33} \mathrm{~S} /{ }^{32} \mathrm{~S}$ and ${ }^{34} \mathrm{~S} /{ }^{32} \mathrm{~S}$ (expressed as $\delta^{34} \mathrm{~S}=\left({ }^{34} \mathrm{R}_{\text {sample }}{ }^{34} \mathrm{R}_{\text {std }}-1\right) * 1000 ; \Delta^{33} \mathrm{~S}=\delta^{33} \mathrm{~S}-((1+$ $\left.\left.\left.\delta^{34} \mathrm{~S} / 1000\right)^{0.515}-1\right) * 1000\right)$ of sulfides in eclogitic veins, serpentinites and hybrid schists from the Lower Shear Zone (LSZ) at Monviso (W.Alps, Italy) recording evidence of an interface-parallel, channelized fluid flow near peak burial metamorphic conditions $\left(\sim 550^{\circ} \mathrm{C}\right.$ and $\left.2.6 \mathrm{GPa}\right)$. For comparison, we also analyzed areas formed by metabasalt, metagabbros and metapelite devoid of metasomatic overprint.

The millimeter to centimeter-sized sulfide crystals found in abundance within LSZ lithologies are mainly pyrites containing inclusions of peak mineral assemblages (e.g. garnet, omphacite, rutile) indicating their crystallization at peak conditions or during incipient exhumation. Sulfides in non-metasomatic metagabbros and metabasalts cover a narrow range in $\delta^{34} \mathrm{~S}$ of $0.89 \pm 0.63 \%$ and $\Delta^{33} \mathrm{~S}$ of $0.017 \pm 0.01(\mathrm{n}=6 ; 2 \mathrm{~s})$ that could be inherited from hydrothermal sulfides formed on the seafloor. Sulfides in the metapelites have a $\delta^{34} \mathrm{~S}$ and $\Delta^{33} \mathrm{~S}$ of -12.08 and $0.041 \%$ respectively, a value typical of sulfides formed by bacterial sulfate reduction. In contrast, sulfides from eclogitic veins, serpentinites and hybrid schists $(n=24)$ are ${ }^{34} \mathrm{~S}-{ }^{33}$ S-enriched $\left(\delta^{34} \mathrm{~S}\right.$ from 4.91 to $21.32 \%$ and $\Delta^{33} \mathrm{~S}$ from 0.02 to $0.06 \%$ ) compared to sulfides from non-metasomatic rocks.

Using two, rather than a single, S-isotope ratios is key to recognize, for example, if isotope variations record a two endmembers mixing that would occur between pre-existing hydrothermal sulfides with e.g. metamorphic fluids evolving during an open-system Rayleigh distillation. In agreement with major and trace elements compositions highlighting enrichment in LILE, $\mathrm{Mg}$, Ni and $\mathrm{Cr}$, our results clearly show the occurrence of ${ }^{34} \mathrm{~S}$-enriched marine sulfates, that are reduced in fluids and mixed with hydrothermal sulfides and/or sediments to produce the appropriate $\Delta^{33} \mathrm{~S}$-signatures. Finally, reduced marine sulfates in fluids could explain ${ }^{34} \mathrm{~S}$-enriched arc lavas but could not be responsible for mantle wedge oxidation. 